\title{
Analysis of Tibetan Female Literature in New Period from Ecological Feminist Perspective_-Take Sun Tribe of Meizhuo as an Example
}

\author{
Daiqiong Liu \\ English Department, Sichuan Minzu College, Sichuan, Kangding 626001, China
}

Keywords: Tibetan female literature, ecofeminism, Sun Tribe, male chauvinism, female consciousness Abstract: From the perspective of ecofeminism, this paper try to tap the relationship between women and nature, between women and men in Sun Tribe write by Tibetan writers Meizhuo. Carding and we found that the motherhood and outlook of women is in harmony with nature which has a natural healing effect, but they are dominated. Very few women have gloom struggle consciousness in patriarchal domination culture, few men are capable of self-reflection and repentance, but women can't change their status of oppression and discrimination. This paper aims to glimpse the ecofeminism in Tibetan female literature by interpret the Sun Tribe, and called for mitigation and even eradicate "natural discrimination" and "discrimination against women” under the "patriarchy" background, and to provide spiritual and cultural support to achieve harmony between humanity and nature, between male and female on the ecological significance.

\section{Introduction}

Since the 1980s, the Tibetan women literature is fruitful and attracted many attentions from other researchers. They analyzed contemporary female Tibetan literature from the multi-perspective of literary sociology and sketched out a clear profile. From the perspective of literary sociology, Hu Peiping discussed the major emergence and development elements of modern Tibetan women literature, then made a review. Yan Xiuying and Xu Qin concerned about its development and prospects. Xu Yin studied on individual Tibetan women writers. As a representative of Tibetan feminist literature in the new era, Meizhuo is good at realistic writing. The unique Tibetan culture and natural environment created the ecofeminism in her works. In view of this, the paper attempts to interpret the female consciousness in Sun Tribe from the angle of ecofeminism, designed to appeal to ease and eradicate the "natural discrimination" and "discrimination against women" under the background of "patriarchy”, to provide spiritual and cultural support to achieving harmony between humanity and nature, between male and female on the ecological significance.

\section{Combination of ecological feminism and Tibetan women literature in New Era}

Ecofeminism was originally proposed by the French feminist Francoise D'Eaubonne in 1974. Eco-feminists believe that women's biological gender role have same purpose with the changes of nature and give birth to all, therefore, there is an intrinsic link between women and nature in the position of being dominated, the nature is ruled by human while women are discriminated by men. Eco-female called an ecological movement to reexamine the relationship between human and nature. The essence of ecofeminism is to expose patriarchy, and value hierarchy thinking, value dualism and the rule logic is the theoretical basis of enslavement women and nature, combining and fundamentally solving the liberation of women and ecological crisis. Western ecofeminism has gone through several stages of development, until the late 1990s, the thoughts began to rise in China.

In the 1950s-1970s, Tibetan literature forum is mainly command by male writers, accordingly, the image of female in literature is created by male writers and detained in the stylized social gender roles mode. The living situation of Tibetan women has been greatly improved with the changes of social system and social context, and the vigorously promote and popularize of modern ethnic education, the 
diversification female social roles, etc. inspired contemporary women writers, stimulate their body awareness, promoting the emergence and development of Tibetan women literature. In early 1980s, Yixizhuoma as the first Tibetan female writer, her short story "Beauty and Ugliness" has win the National Excellent Short Story Award, kicked off the new era of Tibetan women literature. Subsequently, here appearing a number of outstanding property Tibetan writer, such as Yang Zhen, MeiZhuo, Baimanazhen etc. who have gained fruitful results in Tibetan women literature and received numerous awards in related fields. The essence of new women literature is a kind of "Tibetan women narrative" or "Tibetan women write", a literature phenomenon that the creation subject "Tibetan female writers" based on female consciousness and perspective to concerning on Tibetan women's fate, emotion and self-awareness, etc.

Ecofeminism spread in China began around 1995, slightly later than Tibetan women literature in new era. The unexpected meet is an ultimate humane care on nature and the fate of women in female literature. Tibetan women literature touches many aspects like nature, religion, nationality, social and the nature narrative of Tibetan women, and strives for break the tight encirclement of patriarchy and fight for the right to speak, and Meizhuo's Sun Tribe is undoubtedly a typical representative of this category.

\section{Analysis on the eco-feminist in Sun Tribe}

Eco-feminist believes that in the "dualism", men represent the "people", "humanity" and "rational" side, while women represent the "natural”, "animal” or "emotional” side, therefore, male and female, man and nature are hostile to each other. Here, "male" refers the "mankind" in the eco-feminist sense, "female" was "nature" and male is the internal link between female and nature. Thus, carding the relations between women and nature, women and men in Sun Tribe to examine nature and women's "other" and "otherness", and then discussing the ecofeminism in the works.

\section{Relationship between nature and women under patriarchy}

Marx once said that human beings and the natural world is an organic whole, man is a part of nature, there exists an interaction between them, and nature is the basis for human survival and development. Combining Sun Tribe the author try to reveal the status and situation of female and nature under the patriarchal mindset.

First is the harmony of natural beauty of motherhood and the view of life in the novel. At the beginning, the novel describes the land and water plants in Anduo area, "the plant here is bright blue with dignity light which seems like merged with the sky. You can't see its boundary when looking around, just as an unpredictable ocean". All the women in this beautiful scenery is wonderful, like the "sumptuous" precious Yizha madam, "beautiful, elegant, weak and helpless" Yexi, "fairy" Sangdanzhuoma, "wave front sparkling” Xuema etc. whose beauty is complement with natural beauty, and painted a beautiful picture of female blending with nature. In addition, the reincarnation outlook on life and the return of the seasons to complement each other, such as Xuema committed suicide because of lose her virginity and during her lifetime, the repeatedly referred adjourned to love with Zhongxiayixi in afterlife, which is similar with the turnover and transformation of season.

Second, in Sun Tribe, nature and women are facing a similar situation. The perennial conflicts between Yizha and Wosai destroyed the nature, "Yizha is suffering loot...just like Wosai tribes, will become a ruin". Local Serbs obtained food from nature, hunting arbitrarily and killing, which is breaking the ecological balance. Similarly, Tibetan women suffer the oppression both from religious and patriarchal and in a subordinate position, "the A'majunri Mountain" is a female mountain, but absolute prohibited women up to participate in the festival. They thought festival rocks are sacred, and women can just bring bad luck, only men could accomplish the noble and mysterious events, thus, almost none of Yizha women has went to the mountain. Moreover, the nature in Sun Tribe has some healing effect on women, which reappearing in the novel, like every when Sangdanzhuoma feel lonely, 
she will went to the cave behind the forest of Ma river to cry, "she looking around, the walls covered with mother's eyes, the mother said, you cry, you cry...... and she came to cry, facing the mother on wall, against her image motherly love”. In the embrace of nature, various misfortunes and grievances in the heart of Sangdanzhuoma are released, and the mood is appeased. After Luosangdaji left, Sangdanzhuoma is listening to mournful songs and missing her lover, "when the moon rises, Sangdanzhuoma ensure that she can't live without Luosangdaji, because without him, she didn't know the significance of labor. In this mood, the moon slowly rising, slowly, then bright the whole world...the changing light make the night more mysterious, more elusive and more beautiful". In the shinning of moonlight, Sangdanzhuoma's lover really came to her, saying the words from their heart, the moonlight played a remission role to her grief in certain extent. The natural description in the novel is actually a kind of continuation of the female character, a true portrayal of the nature and fate of women, which represents as pay attention to women's living conditions, examining their psychological emotions and expresses life experiences.

\section{Relationship between men and women under patriarchy}

In matriarchal society, women have a higher social status, but with the emergence and development of social production and division, human and male have dominant power to nature and female, resulting ecological damage and female oppression. "Matriarchy was overthrown, and its failure has a historical significance in the world, her husband have mastered the power while the wife was demeaning, enslaved and turning into a slave and a tool to have children”, Engels sharply pointed out the most profound social causes that resulting Zhumu and Peinieluopei's female destiny and character features. Under patriarchal ideology, men are in the highest level, objectified women, thought the slavery on nature and women is justified.

First, at the emotional level, Meizhuo creates many vivid female characters in Sun Tribe and talking about their own love stories. The Hazy struggle sense of Yexi and Xiangsa is a silent protest against patriarchal, which did not bring happiness for them but a tragedy ending. Yexi is indifferent to fame, power and money. In the first night of wedding, she asked the housekeeper Wandazhaxi to elope together who is as silent as a winter cicada; Xiangsa has the sense of rightness and justice, but because of misunderstanding, she ruined the ignorant, sincere and purity love between A'mang, who is never turned back. Wanmacuo is the women cook for lord Suobai, who bring an official position for her husband Zaxiluozhe who gradually despised her, and later she eloped with others. Xuema is facing Caizha's bullies and Wosai's wife is facing tightly onslaught from Suobai, and they all choose to end their lives to defend their dignity. These is a true portrayal on the fate of created characters in the social background, meanwhile, it exposes the cruelty of patriarchal. More or less, Meizhuo has a redemptive attitude toward the fate of women, such as Suobai was influenced by patriarchal ideology, indulge his life and seeking for fame, and finally get on one to warm his heart, which is the punishment on playing women and profane feelings, reflecting the Tibetan Buddhist concept of karma. Meizhuo spend less ink on Wandazhaxi's wife, after her death, Wandazhaxi "suddenly realized that he is charged with a kind of responsibility, for his wife, he thought it was his duty to help his wife go out of the wrong path, this assistance is very simple, in fact, punishing yourself”. Wandazhaxi is using his life to atone for the accident of his wife. Xiazhongyixi and Xuema fall in love with each other, but his weakness and yield pushing Xuema toward the abyss of death, and finally he atone through converted to Buddhism.

Secondly, in Sun Tribe, women were economically dependent on men and can't be truly independent. At that time, the social division of labor has been relatively clear, men are more engaged in the work that can get paid like farming and husbandry, etc. while women are primarily engaged in draw water, brewing wine, spin and weave, milking, boil tea and other can't get paid housework, therefore, women's economic status is low and dominated by men. 


\section{Conclusions}

In Sun Tribe, both nature and women are unable to escape from the discrimination and oppression under the rule of men, however, Meizhuo create a utopian ending. At the end of the novel, A'duo, the daughter of Sangdanzhuoma and Luosangduoji in Yizha tribe together with Gaga, the son of lord Wosai under the guidance of sun stone, carrying the Fengma carved by Jiacuo, and went to Gunwatang to defected to Jiacuo, which is a harmony Shambhala without vendetta and greedy. In the novel, Meizhuo faithfully reproduces the tragedy caused by tribal disputes in Anduo region, reproduces the indelible trauma the patriarchal ideology carrying to nature and Tibetan women. She expressed her expectations between man and nature and the equality between Tibetan men and women, in order to arouse people's dual attention on nature and Tibetan women. Meanwhile, she also gives care and treatment on nature and female, and Gunwatang is that free and beautiful shrine.

\section{References}

[1] Hu P. Study on the emergence of current Tibetan women literature. Alai Research, 2015 (11): 144-152. (In Chinese)

[2] Yan X. 30 year's development brief of Chinese contemporary Tibetan female literature. China Tibetology, 2013 (01): 179-183. (In Chinese)

[3] Xu Q. Persistence and beyond-the creation of Tibetan women writers and discussion and reflection

on the development of Tibetan contemporary literature. Tibetan Studies, 2016 (02): 109-114. (In Chinese)

[4] Hu P. Overview of contemporary Tibetan women literature. Tibetan studies, 2013 (03): 101-108. (In Chinese)

[5] Liu C. Robust $H_{\infty}$ control for satellite attitude control system with uncertainties and additive perturbation. International Journal of Science, 2014, 1(2): 1-9.

[6] Chen M. overview on ecological feminist literary. Qilu Journal, 2006 (04): 108-111. (In Chinese)

[7] $\mathrm{Hu}$ P. Study on the emergence of current Tibetan women literature. Alai Research, 2015(11): 144-152. (In Chinese)

[8] Xiao W. Ecofeminism and its ethical culture. Collection of Women's Studies, 2000 (4): 37-41. (In Chinese)

[9] Mei Zhuo. Sun Tribe. Beijing: Library of China Arts, 1998. (In Chinese)

[10]Engels. Study on the derivation of family, private ownership and nation. Selections (Anthologies) of Marx and Engels, Vol. 4, Beijing: people’s Publishing House, 1972: 52. (In Chinese) 